\section{Colofon}

\section{Skippr}

Skipr is een uitgave van Bohn Stafleu van Loghum, onderdeel van Springer Media B.V.

\section{Uitgever}

Ruud Koolen, ruud.koolen@bsl.nl

Hoofdredacteur

Simon Broersma, simon.broersma@bsl.nl

\section{Redactie}

Samira Ahli, Petri Benschop, Ana Karadarevic, Philip van de

Poel, Tea Keijl (eindredactie)

\section{Redactie-adres}

Postbus 246, 3990 GA Houten

Tel. (030) 6383716 redactie@skipr.nl

\section{Aan dit nummer werkten mee:}

Trix Broekmans, Carly Wijs, Roland Engelbracht, Jasper Groen, Jaap van den Heuvel, Monique ten Hagen, Pim Steerneman, Peter van Steen, Willem Wansink

\section{Beeld}

Amke, ANP, Vincent Boon, Fotolia, Jasper Groen, Inge Hondebrink, iStock

\section{Basislayout}

RedactiePartners, Amsterdam

\section{Advertenties}

Jacqueline Stoutjesdijk, j.stoutjesdijk@bsı.nl

(030) 63837 46/ (06)-2483 7427

Jan Peterson, j.peterson@bsl.nl

Tel. (030) 63839 76/(06) 53156081

Richard Arnoldus, r.arnoldus@bsl.nl

Tel. (030) $6383937 /(06) 53156081$

Verkoop Binnendienst:

Maaike de Werdt, Tel. (030) 63836 47,

maaike.dewerdt@bsl.nl

Arbeidsmarkt

Joris Kranenburg, j.kranenburg@bsl.nl

Tel. (030) 6383956

\section{Advertentiemateriaal:}

Advertentiemateriaal kan aangeleverd worden bij:

traffic@bsl.nl. Tel. (030) 6383603

\section{Abonnementsprijs}

208 euro. Studenten ontvangen 50 procent korting.

Abonnementenadministratie

Klantenservice Bohn Stafleu van Loghum, Postbus 246, 3990 GA Houten. Telefoon: (030) 6383736.

Het abonnement kan elk gewenst moment ingaan en wordt automatisch verlengd tenzij twee maanden voor de vervaldatum is opgezegd via het formulier op www.bsl.nl/klantenservice. Als vak blad hanteren wij de opzegregels uit het verbintenissenrecht. We gaan er vanuit dat $u$ het abonnement uit hoofde van uw beroep hebt afgesloten. Bij wijziging van de tenaamstelling en/of adres verzoeken wij $u$ de adresdrager met de gewijzigde gegevens op te sturen naar de afdeling klantenservice of wijzigingen door te geven via het formulier op www.bsl.nl/klantenservice.

\section{Voorwaarden}

Op leveringen en diensten zijn de bij de Kamer van Koophandel gedeponeerde algemene voorwaarden van Springer Media B.V. van toepassing, tevens raadpleegbaar op www.springermedia.nl. De voorwaarden worden op verzoek toegezonden.

Het overnemen en vermenigvuldigen van artikelen en berichten uit dit tijdschrift is slechts geoorloofd met bronvermelding en met schriftelijke toestemming van de uitgever. Het verlenen van toestemming tot publicatie in deze uitgave houdt in dat de Standaardpublicatievoorwaarden van Springer Media B.V., gedeponeerd bij de Kamer van Koophandel te Utrecht onder dossiernummer 3210/635, van toepassing zijn, tenzij schriftelijk anders is overeengekomen. De Standaardpublicatievoorwaarden voor tijdschriften zijn in te zien op www.bsl.nl/schrijven-bij-bohnstafleu-van-loghum/auteursinstructies of kunnen bij de uitgever worden opgevraagd.

ISSN 1876-8695

(C) 2018 Bohn Stafleu van Loghum, Houten

www.skipr.nl

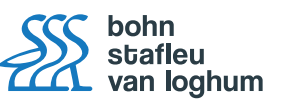

\title{
'Duurzaamheid is waardevol, zeker als je er niet krom voor hoeft te liggen
}

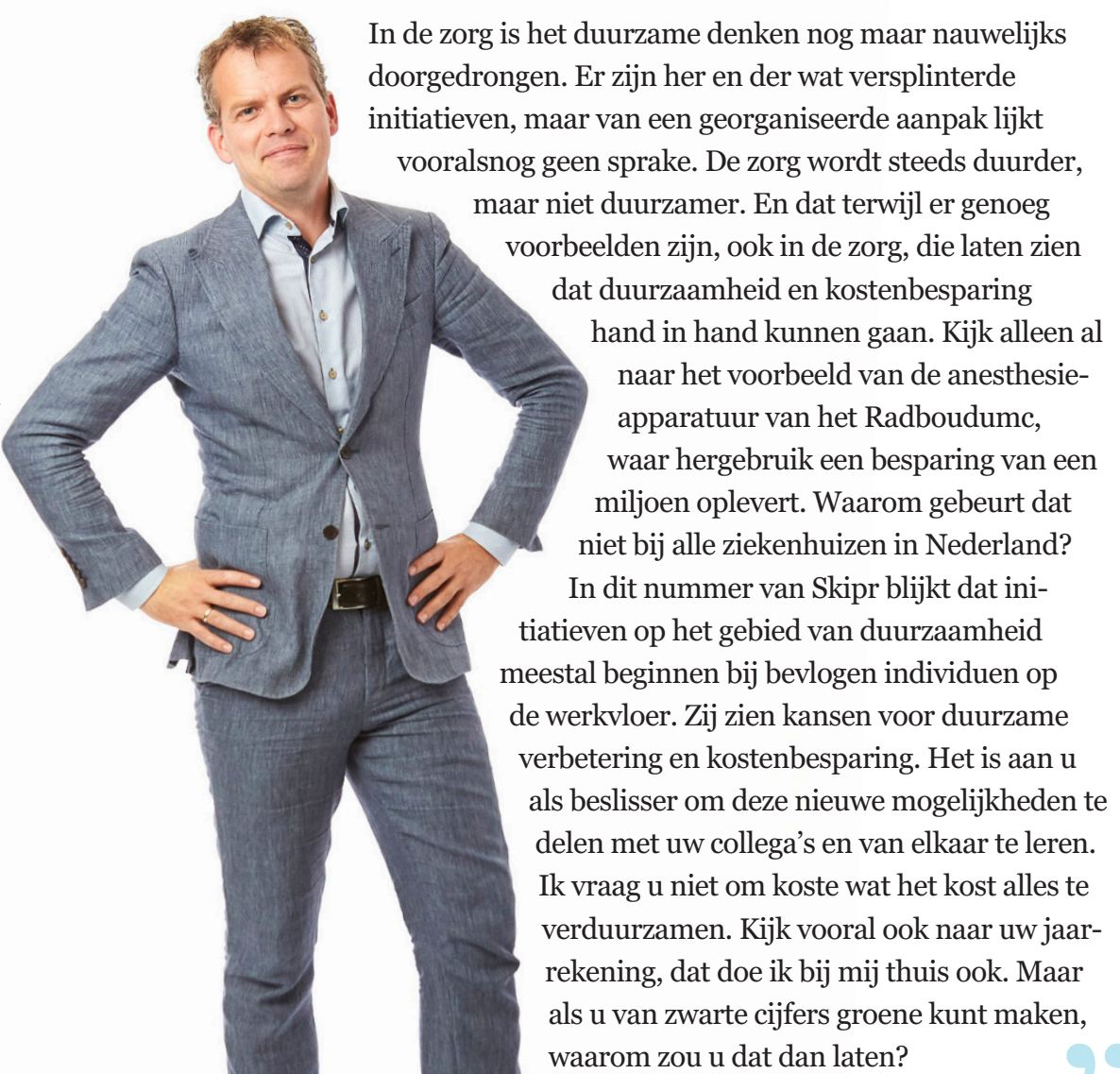

Simon Broersma

Hoofdredacteur Skipr
Ik ben het afgelopen voorjaar verhuisd. Mooi klein nieuwbouwprojectje. Niet te massaal, lekker in het groen. Omdat het nieuwbouw betrof, kreeg ik duizend en één keuzes voorgelegd. Isolatie van de garage? Zonnepanelen? Wel of niet koken op gas? Allemaal zaken die, los van het gebruiksgemak, ook over duurzaamheid gaan. $\mathrm{Nu}$ ben ik geen duurzaamheids hardliner. Ik vind het belangrijk, maar niet koste wat het kost. Sterker nog: ik heb liever dat de duurzaamheid mij op termijn niets kost, maar dat het me wat oplevert. Als echte Nederlander kijk ik natuurlijk ook naar mijn portemonnee. Dus duurzaamheid is waardevol, zeker als je er niet krom voor hoeft te liggen. 